\title{
貯水池結水板の水厚増加について
}

\section{Growth of Ice Covers in Reservoirs}

北見工業大学正員佐 渡 公 明

\section{1. まえがき}

寒冷地の水理構造物に作用する各種の水圧力を算定するのに，水厚は最む重要な要因の一つである。また 眝水池・湖沼・河川等の結水板の耐荷力屯水厚に大きく影響される。このような水厚の值は, 空気中と水中 からの熱収支の結果として定まるものであり, 水と水の 2 相界面が時間と共に移動する一次元熱伝導の相変 化問題である。従来, 乙の問題は, $\mathrm{S}$ tefan ${ }^{1}$, $\mathrm{Neumann}^{2}$, $\mathrm{Kreith}^{3)}$ 等多くの研究者により扱わ机ている。しか しながら,これらは日射量, 風速, 積雪樑等の気象要素の影響を考慮していない。また, ステファン問題と

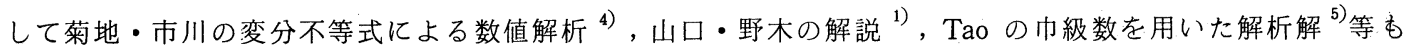
あるが, 応用数学的色採が強く実用的とは言い難い。

本論文の目的は、まず擬似定常の仮定のもとに水板下面における熱収支方程式を解いて、氷厚算定の基本 式を求め, 種々の水厚計算の近似式について適用条件を調べる。乙のとき, 水板表面における大気との熱収 支は, 水板表面温度の非線形関数であるが、線形化して平衡温度と熱交換係数を定義する。特に, 積算寒度 算定の温度として, 水板あるいは積雪の表面温度を使う場合と, 表面上ある高さの気温を使う場合との相違 を明確にする。次に，水厚增加に影響する要因は積雪深，風速等多数あるが，てれらの影響を理論的あるい は実験的に明らかにする。

\section{2. 平衡温度による水厚成長}

\section{2-1 平衡温度之熱交換係数}

図一 1 は眝水池の結水状態を示している。大気の側から積雪表面に出入りす る熱収支要素には, 放射成分として全天日射量 I, 雪面反射日射量 $r \mathrm{I} （ r$ : アルベド），大気長波放射量 $\mathrm{Ra}$ ，雪面逆長波放射量 $\mathrm{R}_{\mathrm{b}}$ がある。また対流成分と しては, 大気と雪面の温度差にもとづく顕熱フラックス $\mathrm{Q}_{\mathrm{H}}$, 雪の蒸発または大

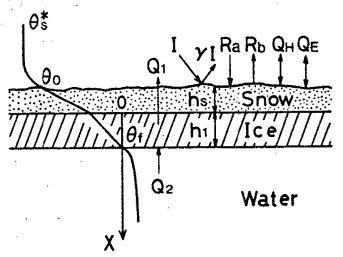

図一 1 結永板の熱収支 気中の水蒸気の雪面への凝結による潜熱フラックス $\mathrm{QE}$ がある。以上の各熱収 支要素の総和である全熱収支量Hsは，雪面に対する加熱を正として次式で表わされる。

$$
\mathrm{H}_{\mathrm{S}}=(1-r) \mathrm{I}+\mathrm{R}_{\mathrm{a}}-\mathrm{Rb}+\mathrm{Q}_{\mathrm{H}}+\mathrm{Q}_{\mathrm{E}}
$$

雪面逆長波放射量，顕熱・潜熱フラックスはそれぞれ次のように表わされる。

$$
\mathrm{Rb}=\sigma\left(\theta_{0}+\delta\right)^{4}, \quad \mathrm{Q}_{\mathrm{H}}=a_{\mathrm{H}}\left(\theta_{\mathrm{ah}}-\theta_{0}\right), \quad \mathrm{Q}_{\mathrm{E}}=\mathrm{LE}, \quad \mathrm{E}=\alpha_{\mathrm{E}}\left(\mathrm{e}_{\mathrm{h}}-\mathrm{e}_{0}\right)
$$

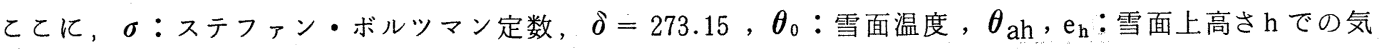
温と水蒸気压, $\mathrm{e}_{0}$ : 雪面上の飽和水蒸気圧, $a_{\mathrm{H}}$ : 顕熱伝達率, $a_{\mathrm{E}}$ : 潜熱伝達率, $\mathrm{L}:$ 昇華の潜熱, $\mathrm{E}:$ 水 蒸気フラックスである。顕熱・潜熱フラックスの算定に, 風による強制対流の他に空気の密度差すなわち安定 度にもとづく自由対流も考慮すると $a_{\mathrm{H}}, a_{\mathrm{E}}$ は $\theta_{0}$ の関数となる。また, 雪面の飽和水蒸気圧は Goff-Gratch やMagnus-Tetens の式から得られるが $\theta_{0}$ の非線形関数である。したがって，式(1)の雪面熱収支量は， $\mathrm{R}_{\mathrm{b}}$ ， $\mathrm{e}_{0}\left(\theta_{0}\right)$ および自由対流を考慮したときの $\alpha_{\mathrm{H}}\left(\theta_{0}\right), a_{\mathrm{E}}\left(\theta_{0}\right)$ のために $\theta_{0}$ に関し非線形である。

式(1)に式(2)を代入して， $\theta_{0}$ に近いある基準温度 $\theta_{\mathrm{B}}$ を使って Taylor 級数に展関し，1 次の項まで取ると次 式が得られる。 $\theta_{0}$ に関する微分を'で表わしている。

$$
\begin{aligned}
& \mathrm{H}_{\mathrm{S}}\left(\theta_{0}\right) \div \mathrm{H}_{\mathrm{S}}\left(\theta_{\mathrm{B}}\right)+\mathrm{H}_{\mathrm{S}}^{\prime}\left(\theta_{\mathrm{B}}\right)\left(\theta_{0}-\theta_{\mathrm{B}}\right)=\mathrm{K}_{\mathrm{S}}\left(\theta_{\mathrm{B}}\right)\left\{\theta_{\mathrm{S}}^{*}\left(\theta_{\mathrm{B}}\right)-\theta_{0}\right\} \\
& \mathrm{K}_{\mathrm{S}}\left(\theta_{\mathrm{B}}\right)=4 \sigma \mathrm{T}_{\mathrm{B}}^{3}-a_{\mathrm{H}}^{\prime}\left(\theta_{\mathrm{B}}\right)\left(\theta_{\mathrm{ah}}-\theta_{\mathrm{B}}\right)+a_{\mathrm{H}}\left(\theta_{\mathrm{B}}\right)-\mathrm{L} \alpha_{\mathrm{E}}^{\prime}\left(\theta_{\mathrm{B}}\right)\left\{\mathrm{e}_{\mathrm{h}}-\mathrm{e}_{0}\left(\theta_{\mathrm{B}}\right)\right\}+\mathrm{L} \alpha_{\mathrm{E}}\left(\theta_{\mathrm{B}}\right) \mathrm{e}_{0}^{\prime}\left(\theta_{\mathrm{B}}\right) \\
& \theta_{\mathrm{S}}^{*}\left(\theta_{\mathrm{B}}\right)=\theta_{\mathrm{B}}+\mathrm{H}_{\mathrm{S}}\left(\theta_{\mathrm{B}}\right) / \mathrm{K}_{\mathrm{S}}\left(\theta_{\mathrm{B}}\right)
\end{aligned}
$$


ここに, $\mathrm{K}_{\mathrm{S}}\left(\theta_{\mathrm{B}}\right)$ と $\theta_{\mathrm{S}}^{*}\left(\theta_{\mathrm{B}}\right)$ がそれぞれ雪面に対する熱交換係数と平衡温度であり， $\mathrm{T}_{\mathrm{B}}$ は $\theta_{\mathrm{B}}$ の絶対温度で ある。従来, 顕熱・潜熱伝達率としては, 強制対流のみを考えて, 雪面上高さ $\mathrm{h}$ での風速 $u_{\mathrm{h}}$ の 1 次関数で 表わした経験式が多数発表されている゙ ${ }^{6)}$ 。乙の場合 $a_{\mathrm{H}}, a_{\mathrm{E}}$ は $\theta_{0}$ に無関係となるので式(4)は，

$$
\mathrm{K}_{\mathrm{S}}\left(\theta_{\mathrm{B}}\right)=4 \sigma \mathrm{T}_{\mathrm{B}}^{3}+a_{\mathrm{H}}+\mathrm{L} a_{\mathrm{E}} \mathrm{e}_{0}^{\prime}\left(\theta_{\mathrm{B}}\right)
$$

と簡単になる。さらに, 基準温度として気温を取ると次式が得られる。

$$
\begin{aligned}
& \mathrm{K}_{\mathrm{S}}\left(\theta_{\mathrm{ah}}\right)=4 \sigma \mathrm{T}_{\mathrm{ah}}^{3}+\boldsymbol{a}_{\mathrm{H}}+\mathrm{L} \alpha_{\mathrm{E}} \mathrm{e}_{\mathrm{o}}^{\prime}\left(\theta_{\mathrm{ah}}\right) \\
& \theta_{\mathrm{S}}^{*}\left(\theta_{\mathrm{ah}}\right)=\theta_{\mathrm{ah}}+\frac{(1-\gamma) \mathrm{I}+\mathrm{R}_{\mathrm{a}}-\sigma \mathrm{T}_{\mathrm{ah}}^{4}-\mathrm{L} \alpha_{\mathrm{E}} \Delta \mathrm{E}}{\mathrm{K}_{\mathrm{S}}\left(\theta_{\mathrm{ah}}\right)}
\end{aligned}
$$

$\mathrm{H}_{\mathbf{S}}\left(\theta_{0}\right)=\mathrm{K}_{\mathrm{S}}\left(\theta_{\mathrm{ah}}\right)\left\{\theta_{\mathrm{S}}^{*}\left(\theta_{\mathrm{ah}}\right)-\theta_{0}\right\}$

ここに, $\mathrm{T} a \mathrm{a}=\theta_{\mathrm{ah}}+\delta, \Delta \mathrm{E}:$ 飽差 $=\mathrm{e}_{0}\left(\theta_{\mathrm{ah}}\right)-\mathrm{e}_{\mathrm{h}}$ である。式(7)の熱交換係数は気温，風速から決まり， 式(8)の平衡温度は気温, 風速, 日射量, アルベド, 大気長波放射量, 相対湿度から求まる。式(3), (9)は, 温 度 $\theta_{0}$ の雪面が温度 $\theta_{\mathrm{S}}^{*}$ の空気に触れているとき， $\mathrm{K}_{\mathrm{S}}$ 熱伝達率として雪面における伝熱量を表わしている。 ある一定の気象条件に対し，平衡温度は大気との熱交換がなく熱的に釣合った平衡状態の雪面温度を表わし， 熱交換係数は雪面温度が $1{ }^{\circ} \mathrm{C}$ 增加したときに雪面が失う総熱フラックスで正の值である。

\section{2-2 水厚計算の基本式}

図一 1 亿示す水板下面 $\left(\mathrm{x}=\mathrm{h}_{1}\right)$ ) 1 次元的な成長や融解を支配する 熱収支方程式は，式(10)である。乙てに， $\rho_{1}:$ 水の密度, $\ell:$ 水の融解

$$
\rho_{1} \frac{\mathrm{dh}_{1}}{\mathrm{dt}}+\mathrm{Q}_{2}=\mathrm{Q}_{1}
$$

潜熱, $\mathrm{h}_{1}$ : 水厚, $\mathrm{t}$ : 時間, $\mathrm{Q}_{1}$ : 水板と積雪を通って大気へ流出する熱流束, $\mathrm{Q}_{2}$ : 水から水板下面へ流入す る熱流束である。 $\mathrm{Q}_{1}, \mathrm{Q}_{2}$ の符号は図一 1 の向きを正とする。

さて, 水板と積雪内の温度分布および上記の雪面熱収支量 $\mathrm{H}_{\mathbf{S}}$ は, $\Delta t$ 時間内は平均值を使うことにより定 常と仮定する。このとき氷板と積雪内の熱伝導および大気の熱伝達から， $\mathrm{Q}_{1}$ は式(11)のように得られる;さら に式(11)を式(10)に代入し， $\mathrm{Q}_{2}$ の $\Delta t$ 時間内の平均值を $\overline{\mathrm{Q}}_{2}$ とすれば式(12)が求まる。

$$
\mathrm{Q}_{1}=\frac{\theta_{\mathrm{f}}-\theta_{\mathrm{S}}^{*}}{\frac{\mathrm{h}_{1}}{\lambda_{1}}+\frac{\mathrm{h}_{\mathrm{S}}}{\lambda_{\mathrm{S}}}+\frac{1}{\mathrm{~K}_{\mathrm{S}}}} \cdots \cdots \cdots \cdots \cdots \cdots(11) \quad \rho_{1} \ell \frac{\mathrm{dh}_{1}}{\mathrm{dt}}=\frac{\theta_{\mathrm{f}}-\theta_{\mathrm{S}}^{*}}{\frac{\mathrm{h}_{1}}{\lambda_{1}}+\frac{\mathrm{h}_{\mathrm{S}}}{\lambda_{\mathrm{S}}}+\frac{1}{\mathrm{~K}_{\mathrm{S}}}}-\overline{\mathrm{Q}}_{2}
$$

ただし， $\theta_{\mathrm{f}}=0{ }^{\circ} \mathrm{C}, \mathrm{h}_{\mathrm{s}}$ は積雪深, $\lambda_{1}$ は氷の熱伝導率, $\lambda_{\mathrm{s}}$ は雪の熱伝導率である。式(12)を初期条件 $\mathrm{t}=0$ で $\mathrm{h}_{1}=\mathrm{h}_{\text {in }}$ のあとに積分し, $\Delta t$ 時間で水厚が $\Delta \mathrm{h}_{1}$ 成長した $\left(\mathrm{t}=\Delta t\right.$ で $\left.\mathrm{h}_{1}=\mathrm{h}_{\mathrm{in}}+\Delta \mathrm{h}_{1}\right)$ とすると, 次の $\Delta \mathrm{h}_{1}$ に関する超越方程式が得られる。

$$
\begin{aligned}
& \frac{\lambda_{1}\left(\theta_{\mathrm{S}}^{*}-\theta_{\mathrm{f}}\right)}{\overline{\mathrm{Q}}_{2}^{2}} \log _{\mathrm{e}}\left|1+\frac{\overline{\mathrm{Q}}_{2} \Delta \mathrm{h}_{1}}{\lambda_{1} \mathrm{~B}\left(\theta_{\mathrm{S}}^{*}-\theta_{\mathrm{f}}\right)}\right|-\frac{\Delta \mathrm{h}_{1}}{\overline{\mathrm{Q}}_{2}}=\frac{\Delta t}{\rho_{1} l} \\
& \mathrm{~B}=1-\frac{\overline{\mathrm{Q}}_{2}}{\lambda_{1}\left(\theta_{\mathrm{f}}-\theta_{\mathrm{S}}^{*}\right)}\left(\mathrm{h}_{\mathrm{in}}+\frac{\lambda_{1}}{\lambda_{\mathrm{S}}} \mathrm{h}_{\mathrm{S}}+\frac{\lambda_{1}}{\mathrm{~K}_{\mathrm{S}}}\right)=1-\frac{\overline{\mathrm{Q}}_{2}}{\mathrm{Q}_{\mathrm{in}}}
\end{aligned}
$$

こてに, $\mathrm{Q}_{\text {in }}$ は水厚が初期水厚のときのQ 1 で式(11)から得られる。式(13)，(14)が水厚算定の基本式である。ただ し, 上記の擬似定常扱いの誤差を少くするためには， $\Delta t$ をそれほど大きく取らないで， $\Delta \mathrm{h}_{1}<\mathrm{h}_{\text {in }}$ を満足 することが必要である。次に式(11)〜(14)を用い， $\bar{Q}_{2}$ を正として，水厚の增减は次のように整理される。

$$
\begin{aligned}
& \theta_{\mathrm{S}}^{*}=0 \cdots \cdots \cdots \mathrm{Q}_{\text {in }}=0 \cdots \cdots \cdots \cdot \mathrm{B}=-\infty \cdots \cdots \cdots \mathrm{h}_{1}<0 \\
& \theta_{\mathrm{S}}^{*}>0 \cdots \cdots \cdots \mathrm{Q}_{\text {in }}<0 \cdots \cdots \cdots \cdots \cdot \mathrm{B}>0 \quad \cdots \cdots \cdots \cdots \cdot \mathrm{h}_{1}<0 \\
& \theta_{\mathrm{S}}^{*}<0 \cdots \cdots \cdot \mathrm{Q}_{\text {in }} \gtreqless \overline{\mathrm{Q}}_{2} \cdots \cdots \cdots \cdot \mathrm{B} \gtreqless 0 \quad \cdots \cdots \cdots \cdot \mathrm{h}_{1} \gtreqless 0
\end{aligned}
$$

\section{$2-3$ 水厚計算の近似式}

水厚算定の基本式(13)は， $\Delta \mathrm{h}_{1}$ を求めるのにてのままでは不便であり陽な形に変形する。対数の中の 
$\overline{\mathrm{Q}}_{2} \Delta \mathrm{h}_{1} / \lambda_{1} \mathrm{~B}\left(\theta_{\mathrm{S}}^{*}-\theta_{\mathrm{f}}\right)$ は, 水厚が成長するとき一般に次のように変形される。

$$
\frac{\overline{\mathrm{Q}}_{2} \Delta \mathrm{h}_{1}}{\lambda_{1} \mathrm{~B}\left(\theta_{\mathrm{S}}^{*}-\theta_{\mathrm{f}}\right)}=\frac{\overline{\mathrm{Q}}_{2}}{\mathrm{Q}_{\mathrm{in}}-\overline{\mathrm{Q}}_{2}} \frac{\Delta \mathrm{h}_{1}}{\mathrm{~h}_{\mathrm{in}}+\left(\lambda_{1} / \lambda_{\mathrm{S}}\right) \mathrm{h}_{\mathrm{S}}+\lambda_{1} / \mathrm{K}_{\mathrm{S}}}<1
$$

$\overline{\mathrm{Q}}_{2}$ が小さく $\mathrm{Q}_{\mathrm{in}}>2 \overline{\mathrm{Q}}_{2}$ が成立し，さらに $\Delta t$ が小さく $\Delta \mathrm{h}_{1}<\mathrm{h}_{\mathrm{in}}$ のときは式(15)の不等号は常に成立する。 式(15)の条件のもとに，式(13)の対数を巾級数に展開し第 2 項まで取ると， $\Delta \mathrm{h}_{1}$ は次のように得られる。

$$
\Delta \mathrm{h}_{1}=\mathrm{B}\left\{\sqrt{\left(\mathrm{h}_{\mathrm{in}}+\frac{\lambda_{1}}{\lambda_{\mathrm{S}}} \mathrm{h}_{\mathrm{S}}+\frac{\lambda_{1}}{\mathrm{~K}_{\mathrm{S}}}\right)^{2}+\frac{2 \lambda_{1}}{\rho_{1} \ell}\left(\theta_{\mathrm{f}}-\theta_{\mathrm{S}}^{*}\right) \Delta t}-\left(\mathrm{h}_{\mathrm{in}}+\frac{\lambda_{1}}{\lambda_{\mathrm{s}}} \mathrm{h}_{\mathrm{S}}+\frac{\lambda_{1}}{\mathrm{~K}_{\mathrm{S}}}\right)\right\}
$$

もし，積雪表面の温度 $\boldsymbol{\theta}_{0}$ が既知の場合は，大気の熱伝達は考慮しなくてよく，式(11)の分母の $1 / \mathrm{K}_{\mathrm{S}}$ が省かれ

$$
\Delta \mathrm{h}_{1}=\mathrm{B}\left\{\sqrt{\left(\mathrm{h}_{\mathrm{in}}+\frac{\lambda_{1}}{\lambda_{\mathrm{s}}} \mathrm{h}_{\mathrm{s}}\right)^{2}+\frac{2 \lambda_{1}}{\rho_{1} \ell}\left(\theta_{\mathrm{f}}-\theta_{0}\right) \Delta t}-\left(\mathrm{h}_{\mathrm{in}}+\frac{\lambda_{1}}{\lambda_{\mathrm{s}}} \mathrm{h}_{\mathrm{s}}\right)\right\}, \mathrm{B}=1-\frac{\overline{\mathrm{Q}}_{2}}{\lambda_{1}\left(\theta_{\mathrm{f}}-\theta_{0}\right)}\left(\mathrm{h}_{\text {in }}+\frac{\lambda_{1}}{\lambda_{\mathrm{s}}} \mathrm{h}_{\mathrm{s}}\right) \quad \text { (17) }
$$

となる。また，積雪がなく水板表面の温度が未知の場合は，式(14)，(16)に $\mathrm{h}_{\mathrm{S}}=0$ を代入し次式が得られる。

$$
\Delta \mathrm{h}_{1}=\mathrm{B}\left\{\sqrt{\left(\mathrm{h}_{\mathrm{in}}+\frac{\lambda_{1}}{\mathrm{~K}_{\mathrm{S}}}\right)^{2}+\frac{2 \lambda_{1}}{\rho_{1} \ell}\left(\theta_{\mathrm{f}}-\theta_{\mathrm{S}}^{*}\right) \Delta t}-\left(\mathrm{h}_{\mathrm{in}}+\frac{\lambda_{1}}{\mathrm{~K}_{\mathrm{S}}}\right)\right\}, \mathrm{B}=1-\frac{\overline{\mathrm{Q}}_{2}}{\lambda_{1}\left(\theta_{\mathrm{f}}-\theta_{\mathrm{S}}^{*}\right)}\left(\mathrm{h}_{\mathrm{in}}+\frac{\lambda_{1}}{\mathrm{~K}_{\mathrm{S}}}\right)
$$

ただし, 式(18)の $\theta_{\mathrm{S}}^{*}$ と $\mathrm{K}_{\mathrm{S}}$ は水板表面の平衡温度と熱交換係数である。さらに，積雪がなく氷板表面の温度 $\theta_{0}$ （雪面温度 $\theta_{0}$ と同じ記号を使っているが混同はないであろう）が既知の場合，式(18)は次のようになる。

$$
\Delta \mathrm{h}_{1}=\mathrm{B}\left\{\sqrt{\mathrm{h}_{\mathrm{in}}{ }^{2}+\frac{2 \lambda_{1}}{\rho_{1} \ell}\left(\theta_{\mathrm{f}}-\theta_{0}\right) \Delta t}-\mathrm{h}_{\mathrm{in}}\right\}, \quad \mathrm{B}=1-\frac{\overline{\mathrm{Q}}_{2} \mathrm{~h}_{\mathrm{in}}}{\lambda_{1}\left(\theta_{\mathrm{f}}-\theta_{0}\right)}
$$

以上の水厚計算式の適用について整理すると，次のようにまとめられる。

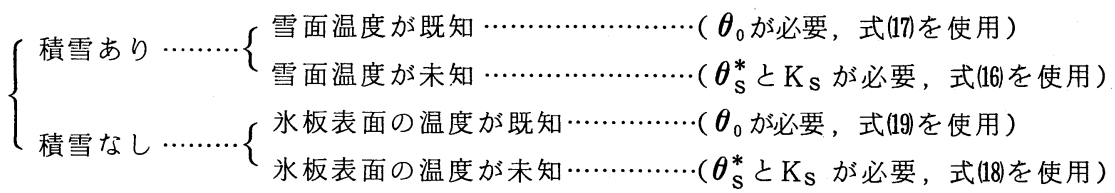

表面温度 $\boldsymbol{\theta}_{0}$ が未知の場合は，平衡温度と熱交換係数を使わなければならない。とのとき，式(8)より気温は， 平衡温度の一部となっている。一般に表面温度よりは気温のデータが入手しやすいので, 気温を使う場合が 多いが，気温と平衡温度の相違が式(8)の右辺第 2 項であり，てれに充分注意しなりればならない。

水から水板下面へ流入する熱流束については，貯水池内の流れが冬期渴水と全面結水のため無視できると すれば, 次のように水温分布を求め, 水板下面の水温の微係数から得られる。最も簡単には, 境界条件を水 板下面で $0{ }^{\circ} \mathrm{C}$, 眝水池底で $4{ }^{\circ} \mathrm{C}$ とし, 初期条件を $0 \sim 4{ }^{\circ} \mathrm{C}$ の直線分布として, 水温に関する非定常 1 次元熱 伝導方程式を解けばよい。水深が浅く水温に眝水池底地盤の地温の影響がある場合には，水温と地温に関す る熱伝導方程式を適当な境界条件と初期条件のもとに解くこともできる7)。貯水池の流れが無視できない場 合には，Kolesnikovの $Q_{2}$ と流速の関係を示す図を利用することができる ${ }^{8)}$ 。しかし基本的には，ヌッセル ト数をレイノズル数とプラントル数の関数で表わせばよいのであるが，今後検討していきたい。

水厚成長に関する Stefan の第 1 近似式は，水温を一様に $0{ }^{\circ} \mathrm{C}$ しているため，式(19)で $\overline{\mathrm{Q}}_{2}=0$ すなわち $\mathrm{B}=1$ とし, $\mathrm{h}_{\text {in }}=0$ とした $\mathrm{h}_{1}=\sqrt{2 \lambda_{1} /\left(\rho_{1} \ell\right)} \sqrt{\left(\theta_{\mathrm{f}}-\theta_{0}\right) t}$ である。 $\left(\theta_{\mathrm{f}}-\theta_{0}\right) t$ は, 結水開始 $(\mathrm{t}=0)$ から $\mathrm{t}$ 時間の間の水板表面温度の平均値を $\theta_{0}$ としたときの積算寒度である。Neumannの解は, 静水からの 慮してS tef an の解を拡張しているが, やはり一定な水板表面温度を用いている。したがって, Neumann や S tef an の解は，積雪がなく氷板表面温度が既知の場合にのみ適用できる。

\section{3. 水厚に影響する要因}

\section{$3-1$ 理論的検討}

水厚増加に影響する要因を空気中，積雪・氷板，水中に分けて分類すると次のようになる。まず，水板之 大気との間の熱交換には，I，rI の短波放射と $R_{a}, R_{b}$ の長波放射加成る放射成分に加えて $\mathrm{Q}_{\mathrm{H}}, \mathrm{Q}_{\mathrm{E}}$ の対 
流成分怔ある。乙の放射と対流成分は，表面において全熱収支量 $\mathrm{H}_{\mathrm{S}}$ となり，平衡温度と熱交換係数を形成している。皘雪と水板内には 温度勾配にもとつく熱伝導加ある。特に, 皘雪深 $\mathrm{h}_{\mathrm{s}}$ を水厚に換算す ると $\left(\lambda_{1} / \lambda_{\mathrm{s}}\right) \mathrm{h}_{\mathrm{s}} \doteqdot(3 \sim 78) \mathrm{h}_{\mathrm{s}}$ となり積雪の断熱効果加著しい。水 板下の水中では，冬期間の密度分布は安定しており自由対流は生じ ない。氷板下面へ流入する $\mathrm{Q}_{2}$ は, 静水時には熱伝導, 流れがあると きは流速変動にもとつく乱流熱伝達によって決まる。

次にいくつかの計算例を示す。以下の計算では $\rho_{1}=0.917 \mathrm{~g} / \mathrm{cm}$ $\ell=79.7 \mathrm{cab} / g, \lambda_{1}=0.0053 \mathrm{cab} /(\mathrm{cm} \mathrm{S} \mathrm{O})$ を用いている。まず，図一 2 は水厚成長江対する平衡温度と熱交換係数の影響を示している。 $\overline{\mathrm{Q}}_{2}=0, \mathrm{~h}_{\mathrm{in}}=\mathrm{h}_{\mathrm{S}}=0, \Delta t=1$ 日 の条件で式(18)から $\Delta \mathrm{h}_{1}$ を求めて いる。図中の $\ell \mathrm{y}$ は $1 \ell \mathrm{y}=1 \mathrm{col} / \mathrm{cm}^{2}$ である。 $\theta_{\mathrm{S}}^{*}$ が低く（絶対值は 大きい)，また $\mathrm{K}_{\mathbf{S}}$ が大きいほど水厚が成長しやすいことが分かる。 したがって (1-r)I， $\mathrm{R}_{\mathrm{a}}$ および相対湿度が增加すると $\theta_{\mathrm{S}}^{*}$ が增し $\Delta \mathrm{h}_{1}$ は減少する。強制対流のみを考虑した $\mathrm{Q}_{\mathrm{H}}, \mathrm{E}$ の典型的な式 ${ }^{6)}$

$$
\mathrm{Q}_{\mathrm{H}}=0.38 u_{1}\left(\theta_{\mathrm{a}_{1}}-\theta_{0}\right) \ell \mathrm{y} / \mathrm{hr}, \mathrm{E}=1.0 \times 10^{-3} u_{1}\left(\mathrm{e}_{1}-\mathrm{e}_{0}\right) \mathrm{g} /\left(\mathrm{cm}^{2} \mathrm{hr}\right)
$$
を用いると，式(7)，(8)は

$$
\begin{aligned}
& \mathrm{K}_{\mathrm{S}}\left(\theta_{\mathrm{a}_{1}}\right)=4 \sigma \mathrm{T}_{\mathrm{a}_{1}}{ }^{3}+0.38 u_{1}+1.0 \times 10^{-3} u_{1} \mathrm{e}_{0}^{\prime}\left(\theta_{\mathrm{a}_{1}}\right) \mathrm{L} \\
& \theta_{\mathrm{S}}^{*}\left(\theta_{\mathrm{a}_{1}}\right)=\theta_{\mathrm{a}_{1}}+\left\{(1-\gamma) \mathrm{I}+\mathrm{R}_{\mathrm{a}}-\sigma \mathrm{T}_{\mathrm{a}_{1}}^{4}-1.0 \times 10^{-3} u_{1} \mathrm{~L} \Delta \mathrm{E}\right\} / \mathrm{K}_{\mathrm{S}}\left(\theta_{\mathrm{a}_{1}}\right)
\end{aligned}
$$

となり，風速が增すと $\mathrm{K}_{\mathrm{S}}$ は增加するが， $\theta_{\mathrm{S}}^{*}$ は主として $(1-\gamma) \mathrm{I}$ の影 響で增诚する。例えは，夜間の晴天で $\theta_{\mathrm{a}_{1}}=-10^{\circ} \mathrm{C}$ ，相対湿度 $80 \%$ $\mathrm{R}_{\mathrm{a}}$ KBrunt•山本の式を用い, $\mathrm{L}=677 \mathrm{ab} / \mathrm{g}, \mathrm{h}_{\mathrm{in}}=\mathrm{h}_{\mathrm{S}}=0, \Delta t=12 \mathrm{hr}$ $\overline{\mathrm{Q}}_{2}=0$ のを， $\mathrm{K}_{\mathrm{S}}, \theta_{\mathrm{S}}^{*}, \Delta \mathrm{h}_{1}$ は風速と共に次表のように増加する。

\begin{tabular}{r|rrrrr}
\hline$u_{1}(\mathrm{~m} / \mathrm{s})$ & \multicolumn{1}{c}{} & \multicolumn{1}{c}{1} & 2 & 5 & 10 \\
\hline $10^{4} \mathrm{~K}_{\mathrm{s}}\left(\ell_{\mathrm{y}} / \mathrm{S}^{\circ} \mathrm{C}\right)$ & 0.988 & 2.48 & 3.96 & 8.43 & 15.9 \\
$\theta_{\mathrm{S}}^{*}\left({ }^{\circ} \mathrm{C}\right)$ & -36.0 & -20.8 & -17.0 & -13.6 & -12.2 \\
$\Delta \mathrm{h}_{1}(\mathrm{~cm})$ & 2.1 & 2.9 & 3.5 & 4.9 & 6.0 \\
\hline
\end{tabular}

圀- 3 は $\overline{\mathrm{Q}}_{2}=0, \theta_{0}=-10^{\circ} \mathrm{C}, \mathrm{h}_{\mathrm{in}}=1 \mathrm{~cm}, \Delta t=1$ 日の条件のもと K， $\Delta \mathrm{h}_{1}$ に対する積雪深と雪の密度の影響を式(17)ら計算したもの である。雪の熱伝導率 $\lambda_{\mathrm{S}}\left(\mathrm{cob} / \mathrm{cm} \mathrm{S} \mathrm{C}^{\circ}\right)$ Kは，密度 $\rho_{\mathrm{S}}\left(\mathrm{g} / \mathrm{clll}^{\circ}\right)$ との

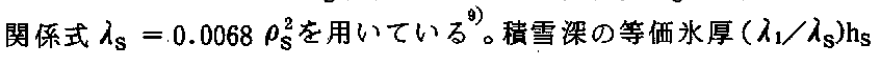
加ら分加るように，密度加軽く積雪深が深いほど著しい断熱効果 があり，氷厚が成長しにくいととが示されている。

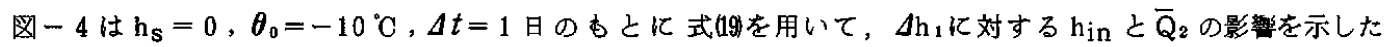
あのである。 $\Delta \mathrm{h}_{1}>\mathrm{h}_{\text {in }}$ の範囲では式(13における対数の級数展開の近似が悪くなるので破線で示している 。流速が大きくなると $\overline{\mathrm{Q}}_{2}$ は增加し，とのとき $\Delta \mathrm{h}_{1}$ は当然であるが減少する。曲線と横軸との交点では $\mathrm{Q}_{\text {in }}$ $=\overline{\mathrm{Q}}_{2}$ となり $\Delta \mathrm{h}_{1}=0$ である。初期水厚が增えると水板内の温度勾配が娍るためQ

\section{3-2 実験的検討}

低温室内の結水実験に用いた鉄製水槽は $1.5 \mathrm{~m} \times 1.0 \times 0.7$ （深さ）の大きさで, 㑡面と底面の外側をグ

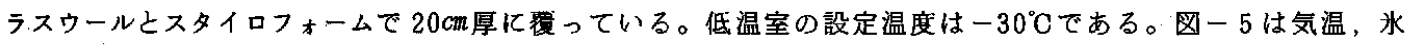
温, 水温の分布を示している。水厚 $\mathrm{h}_{1}$ が50 cm程度までの水板では, 温度分布は直線近似できることが分かる。

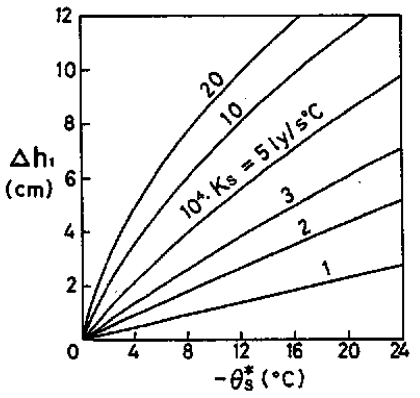

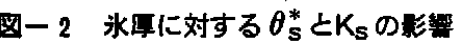

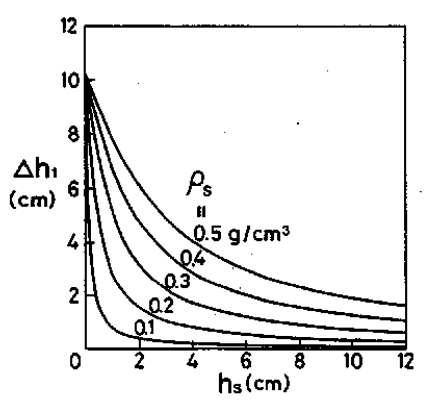

図一 3 水栗に対する $h_{s}$ と $\rho_{s}$ の影䈏

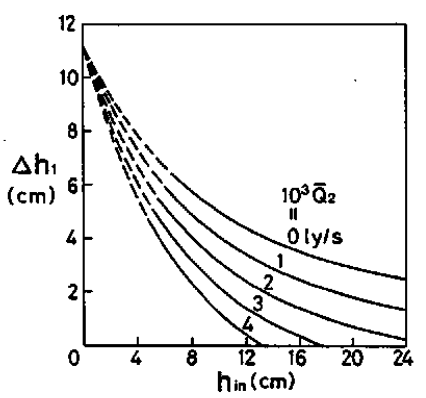

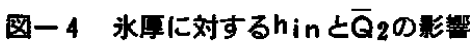


また氷板下面の水温勾配は, 経過時間 $t$ と共に小さくなって いる。水温測定用の CC 熱電対は殆んどが $1 \mathrm{~cm}$ 間隔に設置さ れているので, 水板下面に最も近い水温を用いて氷板下面の 微係数を近似的に求め, 2 時間平均の $\overline{\mathrm{Q}} 2$ を示したのが図一 6 である。 $\bar{Q}_{2}$ は結水直後は大きな值であるが， 2 日以降は非 常に小さくなっている。てれは図ー5 加も分かるように， 水体の熱エネルギーは早期に奪われてしまって，43時間以降 水板下面の水温の微係数が非常に小さくなったからである。

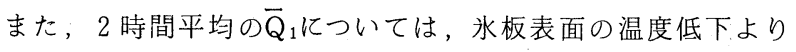
水厚増加の影響が効いて氷温の温度勾配がゆるくなるため, 実験終了の $t=359 \mathrm{hr}$ まで減少し続けている。なお， $t=0$ は水面に扔いて結水開始した時刻である。

図ー7は, 式(19)による氷厚の計算值と実測値を比較した あので, 気温の変化屯示している。水厚の実測值は水槽の中 央付近で測定した 4 箇所の平均值である。 $\theta_{\mathrm{a} 1.5}, \theta_{\mathrm{a} 0.01}$ は水 板上高さ $1.5,0.01 \mathrm{~m}$ の気温である。 $\theta_{\mathrm{a} 0}$ と $\theta_{0}$ は共に水板表面

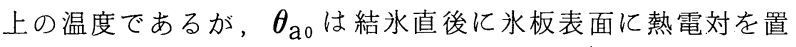
いて測定したもので， $\theta_{0}$ は熱電対のハンダ部分の中心が水面 に一致するように結水前に固定した熱電対の温度である。

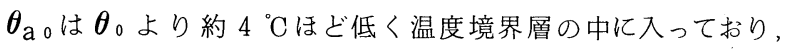

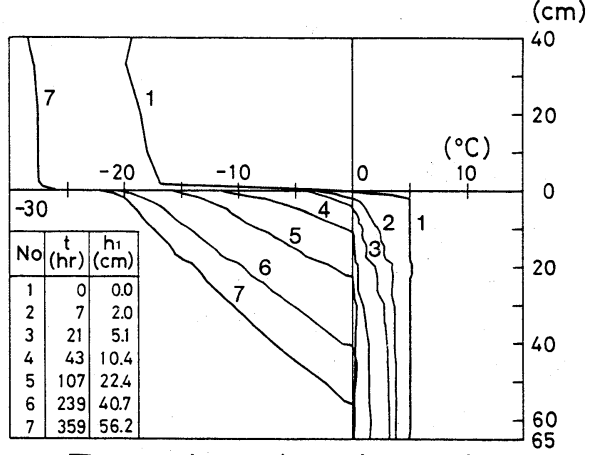

図一 5 気温, 水温, 水温の分布

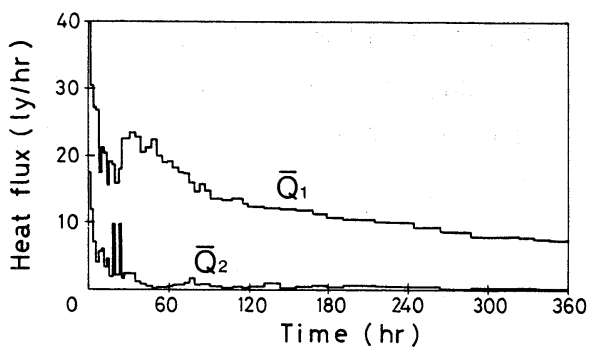

図一 $6 \bar{Q}_{1}, \bar{Q}_{2}$ の時間変化 また氷温分布からも $\theta_{0}$ が真の水板表面温度に近い。図一 7 加水厚の 計算值が実測值に接近してくるのは, 水板表面に近い気温を用い $\bar{Q}_{2}$ を 考慮した場合であることが分かる。乙れは， $\theta_{\mathrm{a} 1.5}<\theta_{\mathrm{a} 0.01}<\theta_{\mathrm{a} 0}<\theta_{0}$ であり，また正確には気温でなく平衡温度を用い式(18)加ら計算しな ければならないからである。形を用い $\bar{Q}_{2}$ を考慮した場合でも計算值が 実測值より多少大きくなっている最大の原因は， $\theta_{0}$ の熱電対が氷板表 面より温度境界層側にやや偏り， $\theta_{0}$ の值が真の表面温度より低くなっ たためと思われる。氷厚増加率 $\mathrm{dh}_{1} / \mathrm{d} t$ が時間と共に小さくなるのは 図一 6 から $\overline{\mathrm{Q}}_{1}-\overline{\mathrm{Q}}_{2}$ が時間と共に減少するからである。なお気温が最 初の頃急激に変動しているのは霜取りヒータが作動したからである。 水厚の実用計算には, 積算寒度 $\mathrm{S}$ を用いた算定式 $\mathrm{h}_{1}=\mathrm{KS}^{\mathrm{n}}$ が簡便で ある。Kは正の定数である。水厚は積算寒度の增加と共に増すので $\mathrm{n}>0$, または氷厚增加率 $\mathrm{dh}_{1} / \mathrm{d} \mathrm{S}=\mathrm{nKS}^{\mathrm{n}-1}$ が積算寒度の増加と共 飞減少しなけ机ばなないので $\mathrm{n}<1$ となり, 結局 $\mathrm{n}$ は $0<\mathrm{n}<1$ の 定数である。ところで積算寒度の計算に用いる気温の測定高さに注意 しなければならない。例えば, 図ー8 8 は上記水槽実験に扔いて得られた 水厚之積算寒度の実測值加ら求めた回帰直線（相関係数は $0.997 \sim$

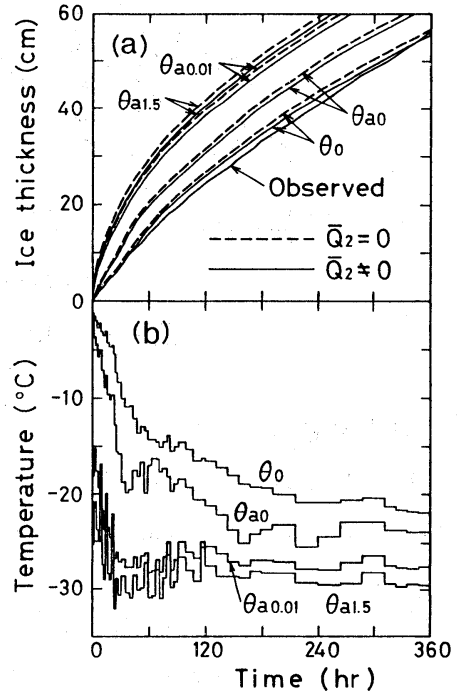

図-7 （a）水厚の計算值ट実測值 (b) 気 温変化 0.999 )を氷板上の高さ別に示したものである。水板上の高さが高く なるほど, 図一 7 から気温が低いので, ある時刻の実測水厚に対して積算寒度が大きく直線の傾きが大きい 。氷板上の高さが低く気温が高くなるほど，Kは増加し $\mathrm{n}$ は減少し， Stefanの式に接近するてとが分かる。 最後に図ー9は, 低温室にある全長 $7.4 \mathrm{~m}$ の台形断面水路（底幅 $10 \mathrm{~cm}$, 側壁勾配 $1: 1$, 全幅 $50 \mathrm{~cm}$ ) を用いて 水厚に対する流速の影響を調べた結果である。図中の $\mathrm{V}$ は結水前の平均流速である。水厚が小さいのは水 
深が $10 \mathrm{~cm}$ 前後と浅いからである。同じ積算寒度であっても流速が大きいほど, 水厚が成長しにくいととが 分かる。乙の最大の原因は, 流速の増加に伴って氷板下面に入る熱流束が增えるからであると思わ机る。

\section{4. 結 語}

擬似定常の仮定のもとに熱収支にもとづいた水厚算定の近似解を誘導した。これらは，積雪の有無および 表面温度が既知か未知かに分けて適用することができる。氷厚増加に影響する要因につうては, 空気中, 積 雪・氷板, 水中に分けて伝熱学的に分類し, 平衡温度, 熱交換係数, 風速, 積雪深, 流速等の影響について 述べた。積算寒度を用いた水厚計算は，積雪がなく，水板表面の温度が既知の場合に誤差が少い。

こてで述べた氷厚成長は真水（black i ce）に関するものである。氷板上の積雪に水が浸透して凍ったゆ き氷あるい性板下面に付着した水泥は，特に河川の水厚と密接な関係があるがここでは省略した。 平衡温度は表面の熱収支を扱うときに非常に重要な温度であり，例えば融雪に対して最も重要な気象要素は 気温でなく平衡温度であると思われる。ただし，その測定がやっかいなのである。今後の課題は，2 相ステ ファン問題の解との比較および水から水板下面へ流入する熱流束の評価である。

最後に本研究の実験に㧍いて, 北見工業大学中尾隆志助手, 開発工学科卒業生松倉俊雄君, 鈴木健治君に 多くの協力を得た。こてに感謝の意を表します。

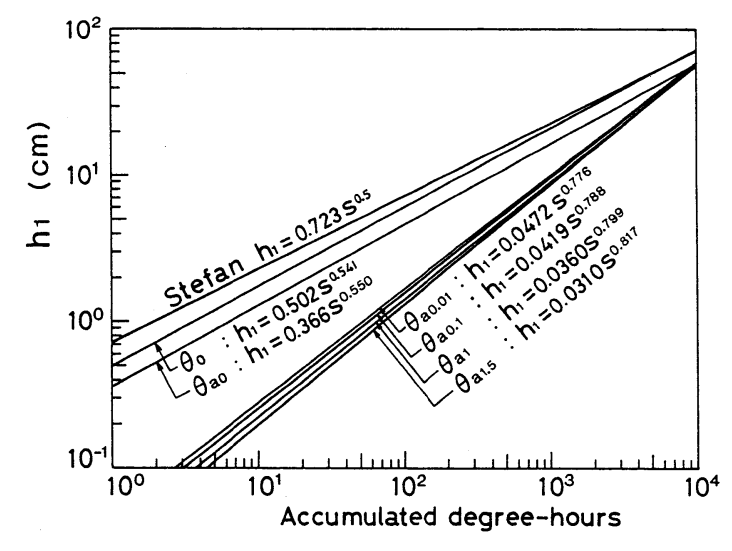

図-8 水厚と積算寒度の関係

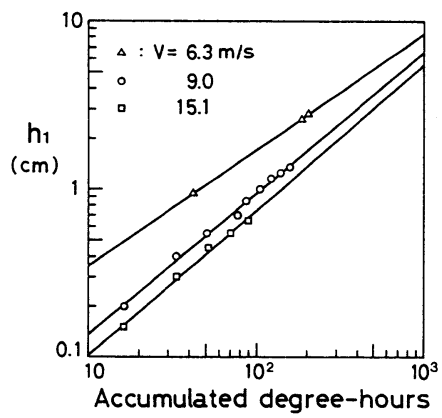

図一 9 水厚に対する流速の影響

\section{参考文献}

1）山口昌哉・野木達夫：ステファン問題, 産業図書, 1977 .

2) Carslaw H.S. and J. G. Jaeger: Conduction of Heat in Solids, Oxford Univ. Press, 1959.

3) Kreith F.: Principles of Heat Transfer, Harper Inter. Ed., 1976.

4）菊地昇・市川康明：変分不等式によるステファン問題，土木学会論文報告集，第 289 号，1979.

5) Tao L. N. : The Stefan problem with arbitrary initial and boundary conditions, Quart. Appl. Math., 1978.

6) 小島䁂治：融䒠機構之熟収支, 気象研究ノ一ト, 第 136 岇, 1979 .

7）佐渡公明：結水河川の水厚に関する一考察，土木学会北海道支部論文報告集，第 35 号，1979.

8) Pivovarov A.A.: Thermal Conditions in Freezing Lakes and Rivers, John Wiley \& Sons, 1973.

9）原田千三:雪・氷・凍土, 丸善, 1943 (絶版). 